\title{
Anthropometric history and the measurement of wellbeing
}

\author{
Bernard Harris ${ }^{1, *}$
}

\section{Abstract}

It has often been recognised that the average height of a population is influenced by the economic, social and environmental conditions in which it finds itself, and this insight has inspired a generation of historians to use anthropometric data to investigate the health and wellbeing of past populations. This paper reviews some of the main developments in the field, and assesses the extent to which height remains a viable measure of historical wellbeing. It explores a number of different issues, including the nature of human growth; the impact of variations in diet and exposure to disease; the role of ethnicity; the relationships between height, mortality and labour productivity; and the "social value" of human stature. It concludes that, despite certain caveats, height has retained its capacity to act as a "mirror" of the conditions of past societies, and of the wellbeing of their members.

Keywords: anthropometrics; height; health; wellbeing; standard of living

\section{Introduction}

As Floud (1997, 1-2) once observed, economic historians have often seemed to place more emphasis on production than consumption. He argued that this emphasis was misplaced, since "the central purpose of economic life and economic growth [is] an improvement in the condition of the people". However, although the reasons for focusing on the condition of the people may seem obvious (especially in a volume devoted to the "demographic aspects of human wellbeing"), the question of how it should be measured has proven much more controversial. This debate has been echoed in the efforts made by students of contemporary societies to examine the

\footnotetext{
${ }^{1}$ School of Social Work and Social Policy, University of Strathclyde, Glasgow, UK

*Correspondence to: Bernard Harris, bernard.harris@strath.ac.uk
} 
relationship between the "condition of the people", the "standard of living", and "wellbeing". As Sen $(1987,1)$ explained:

Within the general notion of the living standard, divergent and rival views of the goodness of life coexist in an unsorted bundle. There are many fundamentally different ways of seeing the quality of living, and quite a few of them have some immediate plausibility. You could be well off, without being well. You could be well, without being able to lead the life you wanted. You could have got the life you wanted, without being happy. You could be happy, without having much freedom. You could have a good deal of freedom, without achieving much. We can go on.

Economic historians have sought to measure changes in the standard of living in a variety of ways, including through the use of income-based measures, such as real wages or GDP per capita, as well as health-based measures (e.g., Feinstein 1998; Clark 2005; Allen 2009), such as age-specific mortality and life expectancy (e.g., Szreter and Mooney 1998). A number of writers have also sought to construct composite indices, such as measures based on the Human Development Index (Floud and Harris 1997; Crafts 1997; Prados de la Escosura 2019) or other combinations, including measures of income, health, time-use and inequality (GallardoAlbarrán and DeJong 2021; see also Jones and Klenow 2016). However, many writers have also attempted to investigate changes in living standards using a range of anthropometric measures (Steckel 1995, 2009; Galofré-Vilà 2018). The vast majority of these studies have focused on the analysis of changes in average height, although some have also investigated changes in weight and BMI. ${ }^{1}$

As Steckel (1995) explained more than 20 years ago, the average height of a population offers a number of advantages as a measure of living standards and wellbeing. First, it is itself a form of composite measure, since it reflects the net impact of the dietary resources consumed by human beings, and the demands made on those resources by energy use and, in particular, disease. Second, it has functional consequences that individuals might themselves have "reason to value" (Sen 1999, 14), such as lower mortality, higher earning capacity, and even general happiness (see also Deaton and Arora 2009). Height data also have the advantage of being available for periods and places for which other data, such as wage or mortality data, may be lacking. This has become even more true in recent years, as new investigations have highlighted the availability of skeletal records, which have been used to extend the anthropometric record back into the very distant past (Galofré-Vilà et al. 2018; Steckel et al. 2019).

However, although the use of height data has become increasingly popular in recent years, it has also provoked criticism. Some authors have questioned the value of height data on the grounds that there is "no way of measuring the exchange rate

1 The BMI, or body mass index, is equal to weight in kilogrammes divided by the square of height in metres. 
of height for real income" (Crafts 1992, 428). Others have debated the conclusions drawn from specific studies, either because of disagreements over the use of particular statistical procedures (see, e.g., Komlos 1993a), or because of doubts about the impact of possible selection biases (Bodenhorn et al. 2013, 2015, 2017). A third group of authors have drawn attention to the issues raised by claims that height is particularly sensitive to the consumption of certain foodstuffs (Mokyr and Ó Gráda 1996), while others have suggested that the value of international height comparisons may be vitiated by the impact of ethnicity (A'Hearn 2016). Some of the assumptions that underpinned the initial contributions to this debate have also been thrown into doubt by improvements in our understanding of the physiology of human growth (see, e.g., Wells 2016). Moreover, the relationship between height and the economic and environmental factors to which it has been linked may change over time (Alter 2004).

Given these developments, this paper asks whether the average height of a historical population can continue to be regarded as a valuable measure of its wellbeing. The paper begins by looking at the background to the emergence of "anthropometric history", and then provides a brief summary of the sources that have been used to investigate average height, and of the different factors that are believed to have influenced height. Next, it discusses the literature on the question of "critical periods" and the relationship between child and adult welfare. Section 6 reviews some of the technical debates that have either enlivened or bedevilled the field since the earliest publications, and their relationships to other welfare indicators. Sections 7 and 8 explore the relationship between height and diet and disease, and Section 9 discusses recent attempts to assess the relationship between height and ethnicity. The final sections look at the extent to which height can be used to "predict" aspects of wellbeing in later life, and at the "social" value attached to height in areas such as the marriage market.

\section{Background}

Over the last 40 years, economic, social, demographic and medical historians have explored the use of height data in historical studies in different ways. During the 1950s, 1960s and 1970s, Thomas McKeown and his collaborators argued that the principal causes of the decline of mortality in Britain and in other European countries were improvements in diet and in the "standard of living" (McKeown and Brown 1955; McKeown and Record 1962; McKeown et al. 1972; McKeown 1976). Yet this conclusion was (and has remained) highly contentious (for a recent summary, see Harris and Helgertz 2019). Fogel et al. $(1978,42)$ argued that one of the reasons for this uncertainty was "the virtual absence of data bearing on the amount and nutritional adequacy of the food supply", and suggested that height data might provide an indirect way of addressing this knowledge gap. However, it soon became apparent that using height data might be less straightforward than it initially appeared, because height is not simply a measure of dietary input, but also reflects 
the demands made on people by a wide range of external factors, including their workload and disease environment (see, e.g., Fogel 1986, 446-7).

Although the study of human height first attracted the attention of many historians in the context of debates about the decline in mortality, it also has profound implications for other debates in economic and social history. As Gallardo-Albarrán and DeJong (2021) have recently highlighted, there has been a (very) long-running debate over changes in the standard of living during the British industrial revolution, and this debate has often turned on the relative importance attached to real wages as opposed to a wider range of welfare indicators. Floud (1984a, 14-15) argued that it is precisely because height reflects the impact of a range of indicators that it has the power to contribute to this debate, as the following extract demonstrates:

To sum up this catalogue of problems, neither computations of the real wage nor those of national income per head seem easily to meet [Daniel] Usher's $(1980,2)$ criterion that they should be more than "mere numbers with no apparent effect upon our lives and no status as indicators of progress towards goals than people might want the economy to achieve". They give us only a most inadequate idea of the impact which the transformation of European society has had upon the lives of Europeans.

This is a dispiriting conclusion. But there has recently emerged an alternative source of information about the welfare of Europeans in the past which will at least supplement, and for some purposes replace, the traditional measures of welfare. This information lies in the millions of observations held in European archives of the physical height of people in the past. It has long been known - both from economic study and from common observation - that people have been growing taller, but it has only recently become clear that that fact carries with it much information about their welfare (Floud 1984a, 14-15).

This debate is directly related to the debates associated with the introduction of the concept of the "biological standard of living" by John Komlos. Komlos $(1987,921)$ argued that the average heights of successive birth cohorts of different sections of the United States population did not always move in the same direction as conventional economic indicators during the years leading up to the outbreak of the US Civil War. ${ }^{2}$ Although the average value of men's heights was declining, the average value of real wages was increasing. Komlos argued that this indicated that a different conception of the standard of living was needed:

The above argument suggests that the human biological system can experience periods of stress even as aggregate output per capita grows significantly. Thus anthropometric measurements do not appear to be

2 This interpretation has been challenged by Bodenhorn et al. (2017); for Komlos's response, see Komlos and A'Hearn (2016, 2019); Komlos (2019) and Section 6 below. 
perfect proxies for the material wellbeing of the population. Rather they might be considered a component of the biological standard of living, which under certain conditions might diverge in significant ways from such conventionally-defined standards as output per capita.

Although the concept of the "biological standard of living" has gained widespread currency in the last 30 years, its value has been challenged. Although height might be regarded as a biological measure of the standard of living (see also Harris 2009, 60), it also needs to be placed alongside other biological measures, such as morbidity or mortality. The distinction between the "biological standard of living" and "material wellbeing" also implies that the concept of material wellbeing can itself be reduced to "such conventionally-defined standards as output per capita". This assertion runs directly counter to the claims made by those who believe that any meaningful concept of the standard of living must also include such factors as "health, longevity and the quality of life" (Floud et al. 2011, 14).

Although many economic historians have advocated the use of height data based on the claim that they provide a "mirror of the condition of society" (Tanner 1987), some writers have argued that height can also be regarded as an important health indicator in its own right. Oddy $(1982,121-5)$ observed that height data enable medical historians to measure the health of past generations directly, rather than relying on the inversion of measures such as mortality - which, as he pointed out, measures the absence of health, rather than its presence. Costa and Steckel (1997, 71-2) also advocated the use of height as a health indicator in their attempts to develop a historical version of the Human Development Index. They noted that contemporary efforts to measure human development are often based on a composite index incorporating measures of GDP per capita, life expectancy and literacy. Although they recognised that height and life expectancy are not precisely analogous, they argued that it is possible to apply this measure to populations for whom mortality data are lacking by substituting height for life expectancy.

Although Costa and Steckel's paper played an important role in demonstrating the value of height data in a wider context, it also highlighted a potential source of tension between approaches that seek to incorporate height into other welfare indexes, and approaches that treat height as a (relatively) comprehensive indicator in its own right. In a previous paper, Steckel $(1992,284)$ had argued that one of the attractions of using height data was the extent to which they capture the influence of a wide range of factors associated with Sen's efforts to measure wellbeing. This tension reflects a longstanding debate between those who regard height as a supplement to conventional measures of wellbeing, and those who believe it offers an alternative to these measures (see also Section 7 below):

Average height is particularly adept at assessing degrees of deprivation, a feature that places the measure nicely within the basic-needs approach to living standards. While the basic needs approach has been criticised for the conceptual problems associated with ascertaining what is basic, in many ways average height finesses this problem because it is a 
measure of net nutrition. Average height incorporates the extent to which individuals have greater needs created by factors such as a harsher disease environment or greater workloads. In this vein, average height is also conceptually consistent with [Amartya] Sen's framework of functionings and capabilities, though, of course, height registers primarily conditions of health during the growing years as opposed to one's status with respect to commodities more generally.

This section has focused on the use of height as a proxy for variables associated with the determination of mortality trends, as a "mirror of the condition of society", and as a health indicator in its own right. However, it could be argued that for height to function as a measure of wellbeing, it also needs to be correlated with other aspects of people's lives, which, in Sen's words, they might have "reason to value" (Sen 1999, 14). Anthropometric historians have sought to explore these dimensions by examining the relationship between height as a summary measure of the living conditions people experience in childhood, and different aspects of people's lives in adulthood. As Floud et al. (2011, 20-5) have argued, height "matters" not only because of what it reveals about the impact of childhood conditions on growth, but also because increases in average height have been associated with improvements in cognitive performance, labour productivity and life expectancy.

\section{Height as a measure of wellbeing}

As the shaded panel of Figure 1 (Data sources) indicates, anthropometric historians have obtained data from a wide range of sources, but the majority of the available data refer to males, and have been derived from populations who were subject to some form of surveillance or control, such as schoolchildren, prisoners and convicts, military recruits, indentured servants and slaves. Other information has been obtained from skeletal remains, passport holders and selected groups of workers, such as postal workers. The nature of these sources has prompted a number of questions about selection biases and representativeness. These issues will be discussed in more detail in Sections 4-6 below.

Although most of the individual variation in stature can be attributed to genetics, some of the earliest investigations highlighted the existence of systematic differences between the heights of different social groups (Villermé 1829, 384-5). As the panel entitled Social, economic and environmental determinants shows, these systematic differences are related to a large number of factors - including income, social status, access to food, personal hygiene, sanitation, air quality, family size, labour organisation and cultural values - that reflect the economic, social and environmental conditions that may prevent people from achieving their genetic height potential. 
Figure 1:

Height as a measure of the standard of living

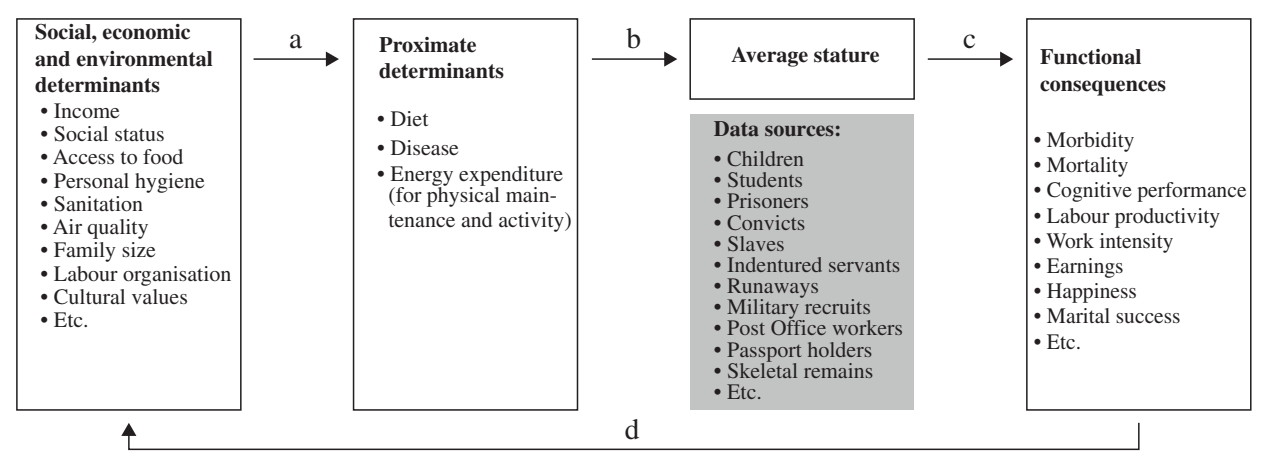

Source: Steckel 1995, 1908, and text.

The next panel in Figure 1 illustrates the proximate determinants through which these social, economic and environmental determinants exercise their effects. The key proximate determinants are diet, disease and the energy required for physical maintenance and activity. These factors interact with each other in different ways. As Fogel and others have argued, height is a measure of net nutrition. It reflects the balance between the nutrients that a person consumes and the demands made by factors such as the "level of physical activity ... climate ... and ... exposure to various diseases" (Fogel 1986, 446-7). The relationship between diet and disease is particularly important. As Eveleth and Tanner (1990, 191-2) explained, exposure to disease can lead to a loss of appetite, while also increasing the body's need for extra nutrition. Moreover, diarrhoeal infections can prevent the body from retaining the nutrients that are consumed.

The Functional consequences panel of Figure 1 highlights some of the functional consequences associated with improvements in stature. These include lower morbidity and mortality, improved cognitive performance and greater work capacity, as well as the prospect of greater happiness and social mobility. These relationships have underpinned the theory of "technophysio evolution", which states that improvements in the height and wellbeing of one generation provide the basis for improvements in the height and wellbeing of subsequent generations (Floud et al. 2011, 1-40).

The theory of technophysio evolution is also illustrated by the arrows linking the different panels. As we have already noted, variations in the average heights of different sections of a population can be linked to systematic differences in a range of social, economic and environmental determinants (Relationship a). These factors influence height through their impact on the proximate determinants of diet, disease and energy requirements (Relationship b). Differences in height can also be associated with a range of functional consequences (Relationship $c$ ). These 
Figure 2:

Boys' velocity standards

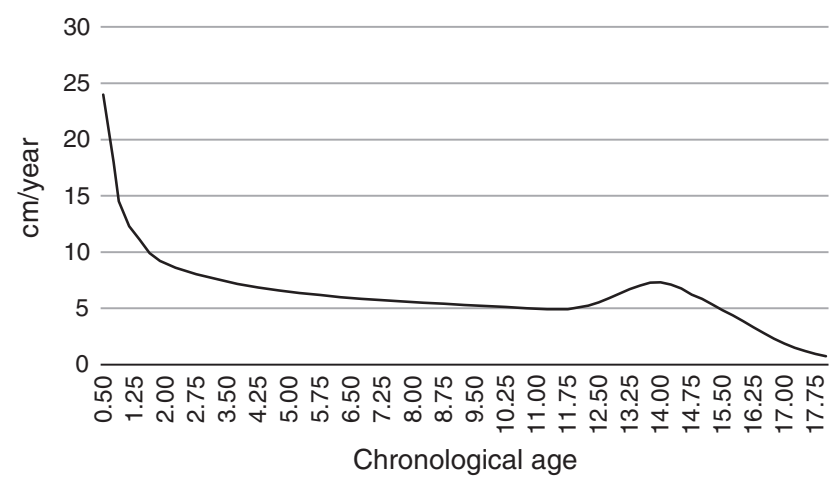

Source: Tanner et al. 1966, 630-631.

functional consequences then exert their own influence on the social, economic and environmental factors that shape the height of the following generation (Relationship d).

\section{Critical periods}

Although the study of anthropometric history is ultimately concerned with groups, the field is based on an understanding of the basic pattern of individual growth. As Figures 2 and 3 demonstrate, individuals grow rapidly during infancy and early childhood, and more slowly between early childhood and adolescence. The rate of growth accelerates at adolescence before slowing down. In countries such as modern Britain, the majority of individuals achieve their mature height between the ages of 16 (in the case of girls) and 18 (boys). However, in the past, it seems likely that the onset of adolescence was often delayed, and that individuals continued to grow at higher ages (see, e.g., Tanner 1990, 157-62; Beekink and Kok 2017). ${ }^{3}$

Height and weight have often been used to monitor the health of both individuals and populations. At the individual level, auxologists use height data to identify children who are pathologically short, and they use growth curves to establish whether children are failing to grow at their expected rates (see, e.g., Tanner 1990, 178-9). However, differences in the average heights of different groups of people

\footnotetext{
3 Although most anthropometric historians have tended to assume that the onset of the adolescent growth spurt was delayed for historical populations, Gao and Schneider (2020) have recently suggested that it may not have occurred at all. If confirmed, this conclusion could have major implications for our understanding of the pattern of human growth in the past and among deprived populations today.
} 
Figure 3:

Girls' velocity standards

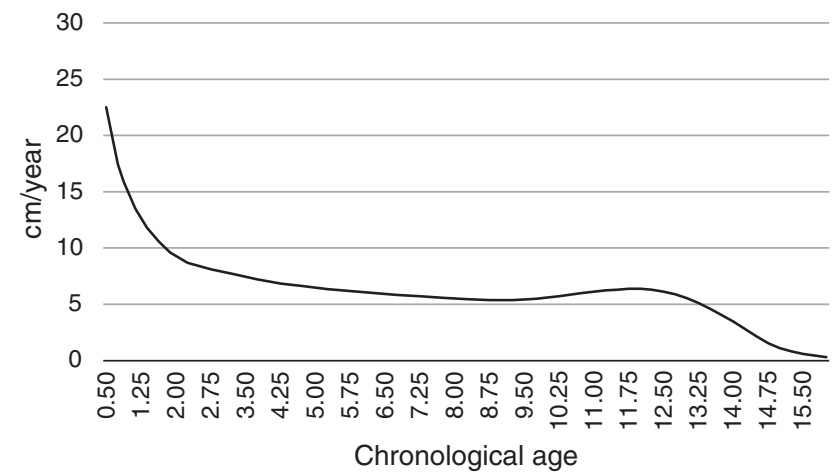

Source: Tanner et al. 1966, 630-631.

can also provide an essential guide to differences in the conditions these groups experienced in childhood. As Eveleth and Tanner $(1976,1 ; 1990,1)$ explained:

A child's growth rate reflects, perhaps better than any other single index, his [sic.] state of health and nutrition, and often indeed his [sic.] psychological situation also. Similarly, the average values of children's heights and weights reflect accurately the state of a nation's public health and the average nutritional status of its citizens, when appropriate allowance is made for differences, if any, in genetic potential.... Thus a well-designed growth study is a powerful tool with which to monitor the health of a population, or to identify sub-groups ... whose share in economic and social benefits is less than it might be.

It has often been argued that children's heights are most susceptible to the influence of adverse conditions during the years in which they should be growing most rapidly. Tanner $(1990,131)$ argued that "in many populations, the period when the child is most at risk from malnutrition, often combined with infection, is six months to three years". Eveleth and Tanner $(1990,194)$ identified the period from birth to five years as most critical, while also arguing that "a second period when the child may be especially sensitive to the influence of undernutrition is adolescence" (ibid., p. 196). This conclusion has recently been echoed by Depauw and Oxley $(2019,925)$ in their analysis of changes in the heights of Belgian prisoners during the $19^{\text {th }}$ century. Although they acknowledged that "it is frequently assumed that 
conditions at birth" had the greatest effect on adult stature, they argued that it was the years between the ages of 11 and 18 that mattered most. ${ }^{4}$

These arguments have important implications for the ways in which we use height and other anthropometric data to measure the health and wellbeing of past societies. If the factors that influence growth only exert a substantial effect during "critical periods", this might limit the extent to which we can use such data to represent social conditions more generally. However, such a conclusion may be premature. For anthropometric historians, two important questions arise: first, to what extent are rates of growth influenced by environmental and nutritional conditions throughout a person's growing years; and, second, what is the relationship between specific periods of infection or nutrition and a person's final (or mature) adult stature?

Unfortunately, we have relatively few data showing concurrent changes in the heights of children at different ages. Harris $(1993,364)$ examined changes in the heights of children in different parts of the UK during and after the First World War, and concluded that "the differences between the heights of children who were born in 1914 and the heights of children born in 1918 may have owed at least as much to conditions around the time of measurement as ... to conditions at the time of birth"; although he also acknowledged that "it is difficult to reach any firm conclusions on the basis of the evidence ... currently available". However, the most famous demonstration of this effect was provided by Howe and Schiller (1952) and Tanner $(1962,121-3 ; 1990,129-30)$ in their accounts of changes in the heights of children attending schools in Stuttgart between 1911 and 1953. Tanner found that "there was a uniform increase at all ages from 1920 to 1940, but in both world wars the height dropped as ... food intakes ... became restricted" (Tanner 1990, 129-30). ${ }^{5}$

The second key question concerns the relationship between childhood experiences and adult stature. Eveleth and Tanner $(1990,195)$ argued that "the question of whether undernutrition in the first one or two years of life necessarily leads to an adult deficit in body size has been discussed frequently and inconclusively", but their overall conclusion was that "much depends on the circumstances obtaining when the severe episode of undernutrition is over" (see also Tanner 1990, 135). In a very influential historical study, Steckel $(1986,724-5)$ found that the relative values of the heights of slave children increased very rapidly from the age of 10 onwards. Prentice et al. $(2013,911)$ have recently argued that "substantial height catch-up

\footnotetext{
4 This issue has also been examined by Kopczyński and Rodak (2020) in their study of the impact of the Polish heights between 1918 and 1939. They argued that the deprivations of the First World War had their greatest effects on the adult heights of children who experienced the war as adolescents. This was because these children had less opportunity to benefit from catch-up growth during the more favourable conditions of the 1920s.

5 Schneider and Ogasawara (2018, p. 65) have recently studied the impact of the disease environment on the growth of children in Japan between 1917 and 1939. They concluded that "the secular increase in height in interwar Japan was more strongly influenced by cumulative responses to the health environment at all ages across development rather than being simply the outcome of improving health conditions in early life".
} 
occurs between 24 mo[nths] and midchildhood and again between midchildhood and adulthood, even in the absence of any interventions". They also cited evidence from their own study of growth patterns in rural Gambia, which showed that "an extended pubertal growth phase allows very considerable height recovery, especially in girls during adolescence" (see also Wells 2016, 373; NCD Risk Factor Collaboration 2020).

One of the main issues raised by this literature is the importance of catch-up growth. If children are exposed to short periods of malnutrition or disease, they may experience a cessation in growth, but they are likely to return to what Tanner $(1990,165)$ described as a "predetermined growth curve" if conditions improve. This suggests that short-term periods of illness or malnutrition are unlikely to have an effect on adult or mature height, and that adult height will be affected only if the adverse conditions continue. However, catch-up growth may not be "costneutral" (Wells 2016, 224). As Singhal (2017, 236-7) has suggested, "there is now compelling evidence that 'accelerated' or too fast growth during critical or sensitive windows in early life has detrimental effects on long-term health, and particularly the risk of obesity and cardiovascular disease"(see also Leon et al. 1996).

These findings have different - and possibly conflicting - implications for our understanding of the relationship between height and wellbeing. If children experience short-term periods of illness or malnutrition, their rate of growth may be temporarily reduced, but they are also likely to return to their predetermined growth curves if conditions improve. However, even if a catch-up process does occur, these periods of disease or malnutrition may be associated with longer-term health deficits. On the other hand, if adverse conditions continue, the children are likely to have a shorter adult height. This suggests that adult height can be a sensitive barometer of the cumulative impact of adverse circumstances throughout the growing years, even if the impact of short-term fluctuations can sometimes be masked (see also Harris 2008a).

\section{Children and adults}

A second problem is presented by the question already highlighted by Richard Steckel (1992, 284): namely, that average heights reflect the impact of living standards on health during the period from conception to maturity "as opposed to one's status with respect to commodities more generally". There are a number of possible responses to this question. One argument is that the height of a child might capture the impact of some aspects of adult health, given that the height of one generation may be determined, at least in part, by previous standards of maternal nutrition. In other words, child and adult heights may reflect the impact of the maternal environment, as they capture some aspect of the welfare of adult women during pregnancy. However, this point would probably be insufficient to counter the view that heights still only capture aspects of human welfare during particular periods of life. 
Steckel's observation also raises an important question about the particular demands placed on people during childhood and the allocation of resources between adults and children. For example, an increase in the demand for child labour might exacerbate the burdens placed on children, but it could also enhance their claims to a larger share of household resources (see, e.g., Floud et al. 2011, 138). Equally, if parents decide to devote more resources to their children, this may enhance the standard of child welfare, without necessarily reflecting a change in the welfare of society as a whole.

Although the majority of anthropometric historians have tended to assume that average heights reflect the experiences of current generations, others have argued that the secular increase in height is an "intergenerational phenomenon, with the offspring of each generation becoming taller than the previous generation, but with the increase in height per generation being tightly controlled" (Cole 2003, 166). However, other evidence suggests that average heights can increase very rapidly when living conditions improve. Gruenwald et al. $(1967,1028)$ estimated that the average height of six-year-old children in Japan increased by between 3.2 and $3.7 \mathrm{~cm}$ from 1945/6 to 1957/8, while Tanner et al. (1982) noted that the average height of Japanese adolescents increased by between 7.9 and $9.7 \mathrm{~cm}$ from 1957 to 1977. Ling and King $(1987,187)$ reported that the average height of Chinese adolescents in Hong Kong increased by between $4.2 \mathrm{~cm}$ and $6.7 \mathrm{~cm}$ from the early 1960s to the early 1980s (see also Harris 2001, 1432).

Although these studies suggest that average heights can increase very rapidly when circumstances change, this does not mean that the problem of intergenerational effects can be discounted entirely. As Wells $(2016,104)$ has explained, several studies have shown that the children and grandchildren of mothers who were exposed to undernutrition in their own lifetimes seem to face a higher risk of obesity. This suggests that even if these children grow to be taller than their forebears, they may still be exposed to medical risks that originated in the experiences of earlier generations (see also ibid., 313).

The use of height as a measure of wellbeing may also be complicated by the relationship between height and mortality. As we shall see, it has often been noted that shorter people are more likely to die at any given age than taller people, leading some observers to point out that this pattern will necessarily inflate the average height of survivors (Alter 2004, 545). Friedman $(1982,502)$ argued that "the mean height of adult males in Trinidad (aged 26-45) who died [during the earlynineteenth century] ... was 0.61 inches $[1.5 \mathrm{~cm}]$ less than for those who survived"; with the result that the "mean height of the survivors was 0.03 inches $[0.01 \mathrm{~cm}]$ taller than that of the initial population". However, these results referred to the impact of deaths that occurred after mature height had been achieved. If mortality occurs at ages when children are still growing, any selection effect is likely to be outweighed by the impact of adverse conditions on the growth of those who survive (Hatton 2011, 2014; see also Prentice et al. 2013, 914).

Regardless of one's views on these questions, there are clearly limits to the extent to which heights provide direct evidence of standards of living after mature height 
has been attained. Some historians have attempted to compensate for this limitation by using evidence of adult weights. Weight is a useful indicator in this context because it continues to change after mature height has been achieved (Horrell et al. 2009, 96). However, it is also more ambiguous, partly because of its subjective element, and partly because being underweight and being overweight can both be indicators of ill-being (Harris 2014, 128).

It is also essential to consider the question of gender. As Osmani and Sen (2003) explained, the study of female heights is important not only in its own right (as an indicator of female wellbeing), but also because of the potential impact of women's nutritional status on the health of their offspring. However, there are relatively few studies of changes in female stature, and many of the studies that do exist have focused on the heights of convicts and prisoners. While these sources have also been used to examine changes in male height, the heights of male and female convicts may not be entirely comparable because of differences in patterns of male and female criminality, as well as in policing and sentencing procedures (Harris 2008b, 165).

Although researchers are beginning to examine a wider range of sources, a consistent picture has yet to emerge. Koepke et al. (2018) have recently compared changes in the heights of men and women in Switzerland using data obtained from passport applicants, convicts, female auxiliaries and mothers attending the Basel maternity hospital. They argued that a secular increase in female heights began a generation earlier than the onset of a similar increase in male heights. However, the evidence from other studies is more mixed. Ezzati et al. $(2016,7)$ argued that "at the turn of the twentieth century, men seem to have had a relative advantage over women in under-nourished compared to better-nourished societies"; whereas Perkins et al. $(2016,152)$ concluded that "sexual dimorphism in stature is more pronounced when undernutrition and childhood disease are mitigated".

One of the main challenges involved in comparing male and female heights is the need to take into account social and economic factors on the one hand, and physiological differences on the other. Tanner $(1962,127-8)$ argued that girls are more resistant to the effect of adverse circumstances because they show greater powers of canalisation, or homeorrhesis. Although the concept of canalisation has been questioned, it might help to explain why other studies have also found that the heights of past generations of girls appeared to compare more favourably with the heights of current generations than was the case for their male counterparts (see also Harris 2009). ${ }^{6}$

6 The concept of canalisation was introduced by the geneticist and developmental biologist, C. H. Waddington, who argued that "developmental reactions, as they occur in organisms submitted to natural selection, are in general canalized. That is to say, they are adjusted so as to bring about one definite end-result regardless of minor variations in conditions during the course of the reaction" (Waddington 1942, 563). This implies that children should grow at the same rate, relative to the rest of the population, throughout their growing years. Although it is widely used, it has not been accepted 


\section{Truncated samples and selected populations}

Although many authors would agree that, in principle, height data provide an important index of wellbeing, there have been a number of significant disagreements over the main trends in height in particular contexts. There is, for example, a longstanding argument about the correct representation of the main trends in height in Britain during the late $18^{\text {th }}$ and early $19^{\text {th }}$ centuries, and there have also been important debates about the representativeness of the height data used to measure changes in wellbeing in both Britain and the United States during the second and third quarters of the $19^{\text {th }}$ century.

In their original study, Floud et al. (1990) argued that there was a slow and irregular improvement in the average heights of successive birth cohorts of British males between the mid- $18^{\text {th }}$ century and the end of the first quarter of the $19^{\text {th }}$ century, but this interpretation of the data has been challenged by Komlos (1993a,b) and other authors (see, e.g., Cinnirella 2008; Komlos and Küchenhoff 2012; Meredith and Oxley 2014). ${ }^{7}$ Although some of the debate has focused on Floud et al.'s analysis of the heights of children who joined the Marine Society between circa 1770 and 1859, most of the controversy has revolved around their analysis of the heights of military recruits. Critics have challenged Floud et al.'s decision to pool data from different military sources, and they have also questioned the estimation procedures the authors used to extrapolate from the heights of military recruits to the (male) population as a whole. ${ }^{8}$

In addition to raising these statistical questions, different authors have attempted to support their interpretations of the data by comparing them with indicators that can be regarded as proximate determinants of welfare, such as real wages or food availability; or with other indicators, such as mortality, which could be regarded either as alternatives to stature or as indirect determinants of it. Komlos (1993b, 365 ) sought to reinforce his initial critique of Floud et al. by highlighting evidence suggesting that average food supplies had deteriorated. However, this argument has also been challenged. Indeed, in their latest contribution, Harris et al. (2015)

uncritically (see, e.g., Hermanussen et al. 2001). These authors also found, contra Tanner, that "growth in boys appeared slightly more canalised than in girls" (pp. 163, 166).

7 Galofré-Vilà et al. $(2018,87-8)$ also found evidence of a small decline in average heights during the course of the $18^{\text {th }}$ century in their study of skeletal remains. However, they were careful to point out that their conclusions were based on very small sample sizes, and may have been distorted by changes in the composition of the population from which their samples were drawn.

8 As Floud et al. $(1990,118)$ explained, the British Army imposed a number of different minimum height standards to control the flow of volunteers at different times. They advocated the use of Reduced Sample Maximum Likelihood Estimation to compensate for the effects of this variation when estimating the average height of the underlying population. Komlos (1993a,b) claimed that this procedure was flawed, and led to erroneous estimates. He provided a fuller discussion of the use of different methods for correcting for the effects in truncation in 2004 (Komlos 2004). For further responses, see Floud et al. (1993a), Floud et al. (1993b) and Floud et al. (2011, 66-7, 136-8). 
presented evidence that average food supplies rose overall between 1750 and 1850 (see also Harris 2016).

The point of reviewing these debates is not to revisit the technical aspects for their own sake, but to highlight their broader implications for the study of anthropometric history. If we regard stature as an entirely separate measure of the standard of living - which may or may not be implied by the use of such terms as the "biological standard of living" - then there is perhaps less need for it to be correlated with other indicators. However, if we regard stature as an alternative measure of "the" standard of living, then it is more important to show how trends in height may or may not be related to more conventional indicators, where evidence for such indicators exists.

The interpretation of the height data drawn from volunteer samples, including both military recruits and prisoners, has also been called into question by Howard Bodenhorn and his co-authors (Bodenhorn et al. 2013, 2017). Anthropometric historians have tended to organise the heights of mature adults by birth cohorts, either because they believe that the factors that influence height exert their strongest influence during infancy and early childhood, or because they believe that the factors that shape average heights operate from conception to maturity (see also Section 4 above). Bodenhorn et al. argued that we also need to consider the ways in which economic fluctuations might influence the propensity of men and women of different heights either to volunteer for the army or commit crimes. This led them to conclude that the declines in average height observed by students of both antebellum America and mid-19 ${ }^{\text {th }}$-century Britain were both artefacts of selection bias.

Although Bodenhorn et al. were undoubtedly correct to highlight the importance of selection bias, it also important to note at least two caveats. First, it is necessary to acknowledge that their concerns were not new - Floud et al. (1990, 115-8) discussed the impact of labour market fluctuations on the pool of army volunteers at some length - and their efforts to rework both the UK data and the US data have themselves been challenged (Zimran 2019; Komlos 2019; Komlos and A'Hearn 2016, 2019). Second, Bodenhorn et al.'s conclusions also raise questions about how they see the relationship between height and other welfare indicators. Their work appeared to pose a direct challenge to the role played by anthropometric studies in supporting "pessimistic" accounts of the impact of industrialisation on the standard of living (see, e.g., Bodenhorn et al. 2013, 6-8; ibid. 2015, 8-10; ibid. 2017, 174-5). However, in the conclusion to their 2017 paper, they acknowledged that "mortality rates remained stubbornly high through the early decades of industrialisation ... and in some cases actually increased, as cities became larger and less healthy.... Real wages rarely fell, but there is reason to doubt that feeble nominal wage growth protected the lowest strata from the consequences of food-price shocks" (Bodenhorn et al. 2017, 202). If this is correct, it is legitimate to ask why they believed that these factors should not have also been reflected in the anthropometric record. 


\section{Dietary influences on stature}

As the anatomist, David Sinclair $(1978,140)$ once explained, "the best way of growing tall and heavy is to have tall and heavy parents". This insight has been reinforced by more recent studies, which have suggested that approximately 80 per cent of the variation in height between individuals of European descent (Visscher 2008) or living in modern western societies (Silventoinen 2003) is genetic in origin, with the remainder being attributed to environmental conditions, of which the most important are nutrition and infection. As Eveleth and Tanner $(1976,246)$ explained:

An ill child is a poorly-nourished child, although the extent of slowing down depends on a number of factors. Poorly-nourished children are more susceptible to and more severely-affected by infection than wellnourished children.... Infection in turn lowers the nutritional intake of the child and the vicious spiral continues.

Anthropometric historians have often considered the question of whether some foods may be more nutritious, and therefore growth-promoting, than others. As Floud et al. $(1990,298)$ acknowledged, it has often been assumed that at the end of the $18^{\text {th }}$ century, the Scots and Irish were poorer than the English or Welsh, and yet their children also grew to be taller. They speculated that this pattern may have reflected the extent to which "potatoes and milk, and perhaps also the oatmeal of the Scots, seem to have provided a healthy and balanced diet for those who did not have to fight off urban disease".

The question of whether either the Scots or the Irish owed their relative tallness to the particular characteristics of their staple diets has also been examined by Mokyr and Ó Gráda (1996, 163-4). They suggested that the specific claims made on behalf of the nutritional value of particular foods meant that anthropometric historians needed to "tone down" claims that height provided an alternative, or even superior, guide to the "standard of living". However, they also argued that some of the height advantage enjoyed by Irish recruits may have been caused by selection effects, thus clouding the issue further. ${ }^{9}$

The importance of different kinds of foodstuffs has also been discussed elsewhere. Floud et al. $(2011,162)$ noted that people who were over-dependent on cereal-based diets needed to consume more food in order to obtain the same nutritional benefits. Dasgupta and Ray (1990, 215-6) argued that individuals who consumed high-fibre diets under pre-industrial conditions needed to increase their total consumption by around 35 per cent in order to derive the same nutritional benefits from their diets as people living under more favourable circumstances.

\footnotetext{
9 Grasgruber et al. $(2016,164-5)$ have recently examined the relationship between a wide range of variables and differences in height in 105 countries. They found that potato consumption was correlated positively with height $(r=0.68 ; p<0.001)$, but were unable to explain why. They noted "the significance of potatoes ... is unexpected because of the poor quality of potato proteins, their low consumption rate and a very low "nutrient density".
} 
Other authors have also highlighted the possible importance of meat and, in particular, dairy products. Jörg Baten and his co-authors have argued that variations in milk consumption help to explain regional variations in stature in $19^{\text {th }}$-century Bavaria, Prussia and France (Baten 2009; Baten and Murray 2000), and in other parts of Europe during the time of the Roman Empire (Koepke and Baten 2005; 2008). These findings have been reinforced by contemporary surveys that have also highlighted a positive association between height and milk consumption (Perkins et al. 2016, 153-4; Wells 2016, 302, 362). However, Baten has also suggested that the impact of milk consumption on variations in stature in the latter case may have been mediated by the specific economic situation of the Roman Empire and its high population densities (Meinzer et al. 2019, 238-9).

Although the significance of this issue should not be exaggerated, it does pose a challenge to the idea that height provides a general guide to the "standard of living". As Mokyr and Ó Gráda (1996, 163-4) suggested, if one population was shorter than another because its staple diet was based on wheat rather than potatoes, one would not automatically conclude that its standard of living was poorer. It is, perhaps, for this reason that both Mokyr and Ó Gráda (1996, 163-4) and Baten and Blum $(2014,568)$ argued that height data should be used to complement conventional welfare indicators, rather than being cited as replacements for them.

\section{Height and disease}

As we have already seen, one of the key arguments in favour of using anthropometric approaches is the claim that height is a measure of net nutrition - i.e., that in addition to capturing the effect of dietary inputs, it also reflects the impact of the external demands placed on the body by the environment in which the person lives. These demands might include not only those created by the need for calories for work and physical maintenance, but also the effects of disease. This argument is particularly important in the context of debates about the impact of industrialisation on the standard of living. Proponents of the anthropometric approach have contended that height captures not only the effects of changes in real wages, but also the impact of urbanisation on the disease environment (Floud 1984a).

Auxologists and anthropometric historians have identified a number of different ways in which stature may be affected by disease. First, illness can both suppress appetite and increase the number of calories required to ward off infection. It can also interfere with the absorption of essential nutrients. Children who are subjected to repeated bouts of diarrhoea are likely to grow more slowly if they lack access to nutritional supplementation. As Floud et al. (1990, 245) explained:

Infection affects nutritional status by a number of different mechanisms. These include loss of appetite, energy lost as heat during fever and loss of other nutrients in sweat, vomiting, decreased absorption of nutrients, protein catabolism, and reduced food intake resulting from cultural 
factors. Malabsorption can also result from infestation with intestinal parasites, but the most common and severe cause is diarrhoea, which causes food to pass through the intestine too quickly to be absorbed.

Historians have also highlighted the impact on stature of malaria (Hong 2007) and of hookworm infestation (Coelho and McGuire 1999), while other scholars have pointed to the impact on stature of atmospheric pollution. Sharpe (2012) identified a number of different diseases that can cause stunting, including measles, whooping cough, bronchopneumonia, diarrhoea and rickets. The last of these diseases was found to be associated not only with poor diet, but also with reduced exposure to sunlight due to the dense fog enveloping Britain's cities. Bailey et al. (2018) have recently built on this foundation in their study of the impact of air pollution on the heights of men who completed their army service in Britain between 1914 and the early 1920s. They concluded that coal smoke reduced adult height by almost half an inch $(1.2 \mathrm{~cm})$, and that efforts to clean up Britain's air accounted for approximately 25 per cent of the gain in average male stature between the birth cohorts of the $1890 \mathrm{~s}$ and the 1980s (ibid., 33).

Although most anthropometric historians would accept the premise that height reflects the impact of a wide range of influences, some observers have suggested that this assumption is less of a strength than a weakness. Crafts $(1992,428)$ complained that it is "unclear how to incorporate height in a welfare index" because "no way of measuring the exchange rate of height for real income has yet been devised". It might, however, be argued that in some ways at least, this misses the point. It is precisely because height captures a wider range of influences in addition to real income that its proponents regard it as a superior measure, even if this also means that it is more difficult to relate changes or variations in height to any single cause (see also Floud et al. 2011, 12-13; Steckel 2008, 136; Steckel 2016, 38).

\section{Height and ethnicity}

As we have already seen, anthropometric historians have devoted a great deal of effort to the challenge of identifying trends in average height within individual countries. However, some of the earliest (and most foundational) papers also sought to draw comparisons between countries. After comparing data from 20 countries in different parts of the world, Steckel (1983) concluded that international differences in mean stature were particularly sensitive to variations in per capita income and the degree of income inequality. Floud (1984b, 23; see also ibid. 1994, 23) examined trends in the average heights of men in 11 European countries between the mid- $19^{\text {th }}$ and late- $20^{\text {th }}$ centuries, and concluded that "western European heights have responded entirely systematically, over the past hundred years, to changes in income and disease, just as heights in the modern world respond to similar differences between countries". 
In recent years, it has become possible to study the impact of environmental and genetic factors on height in much more detail, and this has led some authors to suggest that genetic factors may play a larger role in influencing cross-national variations in adult stature. Brian A'Hearn (2016) has recently argued that the distribution of heights in southern Europe correlates quite closely with variations in real wages before 1850 , but less so thereafter. He suggested that this pattern could be explained in part by changes in work intensity (i.e., workers were compensated for reductions in hourly wages by working longer), and in part by changes in the disease environment (including the eradication of malaria). However, when looking at variations in the heights of adult males born during the 1980s, he argued that genetic differences also played an important role.

As A'Hearn acknowledged, this analysis was subject to a number of limitations. In order to measure the impact of variations in the disease environment, he examined differences in life expectancy. It is, however, likely, that much of the variation in life expectancy reflected the impact of cross-national differences in mortality from non-communicable diseases at higher ages. Other writers have preferred to study the correlation between height and child mortality rates (see, e.g., Grasgruber et al. 2014; Grasgruber et al. 2016). These measures also have their limitations, but the correlation between child mortality rates and height in A'Hearn's sample was greater than the correlation between height and life expectancy. ${ }^{10}$

However, other writers have also concluded that genetic factors have played an increasingly important part in explaining contemporary height variations. Grasgruber et al. (2014) explored the impact of a range of factors that have contributed to variations in adult male stature in 45 European territories and their "offshoots" in Australia, New Zealand and the United States. Although they concluded that height was quite closely correlated with a number of economic and socio-economic factors, including nutritional quality, GDP per capita, health expenditure, child mortality and income inequality, they also detected relationships with a number of genetic variables, including the distribution of Y-haplogroup I-M170, the combined frequencies of Y-haplogroup I-M170 and R1B-U106, and the phenotypic distributions of lactose tolerance. They also reported similar, though not identical, conclusions after extending their analysis to include countries in Africa, Asia and Oceania (Grasgruber et al. 2016).

While these findings suggest that genetic factors may play a larger role in determining international variations in stature than was previously supposed, economic, environmental and nutritional factors also continue to be important. Even if the

10 We have data on adult male stature, life expectancy at birth and children's mortality rates for 27 of the countries that A'Hearn examined. The correlation between height and life expectancy was 0.487 $(p=0.01)$, and the correlation between height and child mortality was $-0.569(p=0.002)$. For data on height and life expectancy, see A'Hearn (2016, 769-70); for data on child mortality rates, see https://datacatalog.worldbank.org/dataset/world-development-indicators. The child mortality rate is the average for the period 1980-85, with the exceptions of the Czech Republic (1981-5), Serbia (1984-5) and Slovenia (1981-5). A'Hearn's original study also included results for "Med-Yugoslavia". 
impact of these factors on stature has declined over time, it has not been eliminated altogether. As Grasgruber et al. $(2016,194)$ have argued, "the factors leading to the increase in the average height intertwine with public policies that improve the overall quality of life". Thus, even if the importance of genetic factors has increased, the evidence suggests that height continues to be an important tool for monitoring the success of public policies. Baten and Blum (2012) reviewed the historical evidence on changes in average male stature in 156 countries between circa 1810 and 1989. After "taking into account ... protein availability, disease environment, lactose intolerance and food preferences", they concluded that "the height impact of 'race' seems rather small" (p. S69; see also NCD Risk Factor Collaboration 2020, 1520).

\section{Height, wages and mortality}

The majority of this paper has been concerned with the use of height data as summary reflections of the aggregated impact of factors such as real income, food consumption and disease - all of which have traditionally been associated with the "standard of living". However, an important part of the argument in favour of using height data as indicators of wellbeing is that they also capture aspects of human development that have functional consequences for other welfare measures, including both labour productivity and longevity.

An early illustration of the relationship between height and both longevity and productivity was provided by Friedman's study of the heights of Trinidadian slaves. As we have already seen, he showed that slaves who survived the initial registration period were 0.61 inches $(1.5 \mathrm{~cm})$ taller than non-survivors, and that craftsmen were 0.5 inches $(1.25 \mathrm{~cm})$ taller than fieldhands (Friedman 1982, 488-9). Similar results were reported by Margo and Steckel (1982) and Costa (1993). These findings have also been echoed in studies of more recent societies. Waaler (1984) showed that shorter people are more likely to die at younger ages, and Schultz (2002) demonstrated that taller people enjoy higher wages. Deaton and Arora (2009) concluded that height is positively correlated with both income and education, as well as with happiness and wellbeing.

As we have already seen, height is an important marker of the effects of environmental and nutritional conditions on childhood growth. However, in modern western societies, approximately 80 per cent of the individual variation in height is likely to be due to genetic effects (see Section 7 above). It is, therefore, important to ask what dimensions of stature are being captured by the association between height and other indicators. This question is particularly important when considering historical data. It seems reasonable to assume that environmental factors accounted for more of the variation in individual stature in the past, when a greater proportion of the population was subjected to conditions that were likely to restrict their growth. If this was the case, we might expect the association between height and other 
measures to have been stronger if this association was caused by the impact of early life conditions on adult stature.

One way of approaching this issue is to compare the association between height and mortality in historical and contemporary populations. Both Costa (1993) and Alter (2004) have compared the association between height and mortality within historical populations with Waaler's (1984) analysis of the relationship between height and mortality in mid-20 $0^{\text {th }}$-century Norway. In all three cases, mortality declined as height increased, up to a height of approximately 73 inches $(183 \mathrm{~cm})$, at which point the relationship was reversed. If the association between height and mortality had been caused primarily by genetic factors, the curve should have shifted to the right as average heights increased. The fact that it appears to have remained constant suggests that environmental factors also played a role (see also Harris 1997).

This is a reassuring conclusion for those who believe that improvements in the environmental and nutritional conditions that are associated with adult stature will also lead to reductions in mortality. However, it is important to recognise that the association between height and mortality is also linked to specific causes of death, such as cancer, coronary heart disease and chronic obstructive pulmonary disease; and that there are other causes of death for which height and mortality are correlated positively (Floud et al. 2014, xxxiii; Perkins et al. 2016, 155-7). As the cause structure of mortality changes, we might expect to see further changes in the relationship between height and mortality.

\section{The social value of height}

The preceding sections have focused on the extent to which height can be correlated with other factors associated with the measurement of wellbeing. This has led us to examine factors that influence height and rates of growth, as well as other indicators that may be affected by them. However, it is worth asking whether height also possesses a more "subjective" value as either an index or a dimension of wellbeing. If height is correlated with measures of happiness or "subjective wellbeing", is this because it is also associated with other correlates, or because it is valued in its own right?

In an intriguing paper, Deaton and Arora (2009) compared the heights and weights of more than 450,000 men and women with their positions on a "selfanchoring sliding scale". Respondents were asked to rate their quality of life on a sliding scale of 1-10, with one representing "the worst possible life", and 10 representing the best. They found that "men who are above average height ... report that they are a little more than one-seventh of a step ... above men who are below average height". Moreover, they reported that women whose height was above average were a little less than one-tenth of a step higher on the scale than women whose height was below the average. However, the authors also found that almost all of the difference disappeared after controlling for the effects of income 
and education. In other words, they concluded that if taller people were happier, it was not because they were taller, but because they were wealthier and better educated.

There are, however, some indications that height does have a value of its own. As Floud et al. $(2011,13)$ observed, there is some evidence for this assumption in the "immense effort and expenditure undertaken by some parents of particularly short children to lengthen their children by persuading surgeons to break their leg bones and then ... stretch their legs as they heal". There is also evidence to suggest that height is often a quality we value in others. Several studies have shown that taller men are more likely to marry at younger ages, and are more likely to ever marry, although the reasons why this is the case remain unclear. Murray $(2000,518)$ argued that while women may prefer taller men on cultural or aesthetic grounds, it is also possible that women recognise that such men are likely to be healthier or have better earnings prospects (see also Weitzman and Conley 2014; Yamamura and Tsutsui 2017). Sohn $(2015,111)$ examined the "trade-off" between height and income in Indonesia, and found that while much of the association between male height and marriage was related to income, "there are still other attributes that women look for in male height, and this indicates that there are marriage market penalties for short men".

Although much of the available evidence suggests that height does possess a social value, it does not necessarily follow that societies will always behave in ways that seek to maximise stature. As we have already suggested, height is a measure of net nutritional status "from conception to maturity", and may therefore reflect, at least in part, the extent to which parents are either able or willing to behave in ways that maximise their children's nutritional status. Variations in stature may also reflect the extent to which societies "trade off" some aspects of wellbeing against others. Eltis $(1982,474-5)$ argued that many historical populations may have engaged in "nutritional satisficing" or "aim[ing] for a nutritional target lower than maximum". He argued that this was because they valued "self-employment" over the achievement of more material goals. He also suggested that in many cases, improvements in average stature only occurred when labour was either partially or entirely coerced.

\section{Conclusions}

Eveleth and Tanner (1976, 1; see also ibid. 1990, 1) argued that "a well-designed growth study" was not only "a powerful tool with which to monitor the health of a population", but also a tool "to pinpoint sub-groups ... whose share in economic and social benefits is less than it might be". The link between height, health and "economic and social benefits" was the basis for Tanner's subsequent description of height as a "mirror of the condition of society" (Tanner 1987). To what extent does this claim continue to apply to the study of historical populations? 
This paper began by examining the development of anthropometric history, and of research into the impact of economic, social and environmental factors on variations in human stature. It then explored some of the issues associated with the identification of "critical periods", and efforts to extrapolate from the analysis of male heights to the understanding of differences in welfare between different genders and age groups. It also provided a brief account of the impact on height of both diet and disease, before looking at some recent debates about the impact on stature of "race" and ethnicity. It concluded by examining the relationship between height, wages and mortality, and between height and "subjective wellbeing".

In general, this brief survey suggests that height has retained its capacity to shed light on the welfare of past populations, with some possible caveats. One problem concerns the question of "catch-up" growth among people who experience adverse conditions early in life. There is increasing evidence that even though children especially at the youngest ages - are able to "catch up" if their environmental or nutritional circumstances improve, this may still come at the cost of future health problems. If this is the case, then the ability of these children to return to their "predetermined growth curves" may still mask significant health deficits. If, on the other hand, the children's circumstances do not improve, their final, or mature, height is likely to be lower, and will thus reflect the cumulative impact of the adverse circumstances they experienced throughout their growing years.

The value of height as a measure of welfare is also affected by the role played by particular foodstuffs. Various authors have argued that height is especially sensitive to the consumption of oats, potatoes, milk or other sources of animal protein. Some of these findings may, of course, have been affected by selection issues. However, insofar as growth is affected by the consumption of particular foodstuffs, it is also important to consider the extent to which access to the most nutritious - and growthpromoting - foods is itself related to broader conditions.

Another controversial issue concerns the relationship between height and ethnicity. It has recently been suggested that ethnicity may play an increasingly important role in determining international variations in stature, although this may depend in part on the particular nature of the variables that have been used as proxies for economic and health conditions. However, it still seems likely that international variations in stature would have been more closely associated with variations in economic and environmental circumstances in the past, when the impact of these factors on individual height differences may also have been greater.

The use of height as a measure of wellbeing depends in part on the argument that it can be correlated with a range of causal factors that are broadly associated with the "standard of living", and in part on the claim that it is also correlated with other dimensions of wellbeing that individuals might have "reason to value" (Sen 1999, 14). Two issues that have received particular attention in this context are wages and mortality. However, it is important to remember that the correlations between height and both of these indicators may change over time. Costa $(2015,551)$ has argued that "returns to height in the United States circa the mid-nineteenth century were very low" because they were generally associated with low status occupations, 
but that these returns have increased over time because of the correlation between height and cognitive performance, and the transition "from a brawn- to a brain-based economy".

The relationship between height and mortality is also, in some senses, time contingent. As we have seen, it seems reasonable to suppose that environmental factors had a greater influence on variations in stature in the past than they do today. If the relationship between stature and mortality reflected the relationship between stature and living conditions, we might expect the relationship between stature and mortality to weaken over time. This effect is compounded by changes in the cause structure of mortality. If height is negatively correlated with diseases that are having a declining impact on mortality, we would expect the relationship between height and overall mortality to change accordingly.

Although increases in height have generally reflected improvements in living standards, this relationship may be complicated in other ways. As we have already seen, height is a cumulative measure of the conditions experienced by children from conception to maturity. As a result, in addition to indicating a household's general living conditions, a child's height may also reflect the way in which resources are distributed within the household. In many contemporary societies, it is still common for girls to receive a smaller share of the available resources than their brothers. However, historians have continued to disagree over the extent to which such a gender divide in the treatment of siblings may have existed in the past (see, e.g., Harris 2008b). This is one reason why the relative paucity of data on female heights remains a significant challenge for anthropometric historians.

The long-term history of anthropometric change may also be affected by changes in household size and structure. Previous studies have shown that height can vary with birth order, and that children who grow up in (numerically) large families have often been shorter than children who grow up in smaller families (Öberg 2017). These findings have led a number of authors to conclude that one of the major causes of the improvement in heights during the $20^{\text {th }}$ century was the decline in fertility even though not everyone would see the decision to have fewer children as a form of "wellbeing" (Hatton and Martin 2010; see also Hatton and Bray 2010).

This issue also highlights the potential significance of parental choice in determining children's growth. Although parents do not necessarily "purchase" height (Floud et al. 2011, 13), it is generally assumed that they will seek to obtain the living conditions with which height is often correlated. However, as Eltis (1982, 474-5) argued, many adult populations may - no doubt unintentionally - have reduced their children's growth by prioritising leisure over work. Although he did not discuss this issue at great length, he also speculated that this practice only ceased under conditions in which labour was either partially or entirely coerced.

This is not the only perplexing conclusion that the history of human height has sometimes evoked. In general, as material conditions have improved, children have grown taller and heights have increased. However, a number of scholars have also suggested that some of the largest improvements in stature in earlier periods were preceded by significant disasters. Clark $(2007,101)$ argued that the Black 
Death of 1347-51 "raised living standards all across Europe" in the following years. In a similar vein, some anthropometric historians have argued that "the tremendous reduction of the population during the Justinian Plague and the end of the West Roman Empire had a strong impact on health, because the much smaller population [in number] was likely better nourished" (Baten et al. 2019, 394). Although this interpretation has not gone unchallenged (see Galofré-Vilà et al. 2018, 81-2), it nevertheless provides a rather sobering coda to the long-term history of anthropometric change.

\section{Acknowledgements}

Previous versions were presented to the Annual Conference of the Economic History Society at Queen's University, Belfast, on 6 April 2019; and at a conference on "The demographic aspects of human wellbeing" at the Wittgenstein Centre, Vienna, on 11 November 2019. I am grateful to the editors of this journal and to Gregori Galofré-Vilà, Daniel Gallardo Albarrán and three anonymous referees for their helpful comments.

\section{References}

A'Hearn, B. 2016. The anthropometric history of the Mediterranean world. In The Oxford handbook of economics and human biology, eds J. Komlos and I. Kelly, 765-796. Oxford: Oxford University Press. https://doi.org/10.1093/oxfordhb/9780199389292.013.45

Allen, R. 2009. Engels' pause: Technical change, capital accumulation and inequality in the British industrial revolution. Explorations in Economic History 38(4): 411-447. https: //doi.org/10.1016/j.eeh.2009.04.004

Alter, G. 2004. Height, frailty and the standard of living: Modelling the effects of diet and disease on declining mortality and increasing height. Population Studies 58(3): 265-279. https://doi.org/10.1080/0032472042000272339

Bailey, R., T. Hatton and K. Inwood 2018. Atmospheric pollution, health and height in late-nineteenth century Britain. Journal of Economic History 78(4): 1210-1247. https: //doi.org/10.1017/S0022050718000578

Baten, J. 2009. Protein supply and nutritional status in nineteenth-century Bavaria, Prussia and France. Economics and Human Biology 7(2): 165-180. https://doi.org/10.1016/j.ehb. 2009.02.001

Baten, J. and M. Blum 2012. Growing tall but unequal: New findings and new background evidence on anthropometric welfare in 156 countries, 1810-1989. Economic History of Developing Regions 27(Supplement): S66-S85. https://doi.org/10.1080/20780389.2012. 657489

Baten, J. and M. Blum 2014. Why are you tall while others are short? Agricultural production and other proximate determinants of global heights. European Review of Economic History 18(2): 144-165. https://doi.org/10.1093/ereh/heu003 
Baten, J. and J. Murray 2000. Heights of men and women in nineteenth-century Bavaria: Economic, nutritional and disease influences. Explorations in Economic History 37(4): 351-369. https://doi.org/10.1006/exeh.2000.0743

Baten, J., R. Steckel, C. S. Larsen and C. Roberts 2019. Multidimensional patterns of European health, work and violence over the past two millennia. In The backbone of Europe: Health, diet, work and violence over two millennia, eds R. Steckel, C. S. Larsen, C. Roberts and J. Baten, 381-396. Cambridge: Cambridge University Press. https://doi. org/10.1017/9781108379830.015

Beekink, E. and J. Kok 2017. Temporary and lasting effects on childhood deprivation on male stature. History of the Family 22(2-3): 196-213. https://doi.org/10.1080/1081602X. 2016.1212722

Bodenhorn, H., T. Guinnane and T. Mroz 2013. Problems of sample-selection bias in the historical heights literature: A theoretical and econometric analysis. Center Discussion Papers 148749, Yale University, Economic Growth Center. https://doi.org/10.22004/ag. econ. 148749

Bodenhorn, H., T. Guinnane and T. Mroz 2015. Sample-selection biases and the "industrialization puzzle”. NBER Working Paper Series no. 21249. https://doi.org/10.3386/w21249

Bodenhorn, H., T. Guinnane and T. Mroz 2017. Sample-selection biases and the industrialization puzzle. Journal of Economic History 77(1): 171-207. https://doi.org/10.1017/ S0022050717000031

Cinnirella, F. 2008. Optimists or pessimists? A reconsideration of nutritional status in Britain, 1740-1865. European Review of Economic History 12(3): 325-354. https://doi.org/10. 1017/S136149160800227X

Clark, G. 2005. The condition of the working class in England, 1209-2004. Journal of Political Economy 113(6): 1307-1340. https://doi.org/10.1086/498123

Clark, G. 2007. A farewell to alms: A brief economic history of the world. Princeton: Princeton University Press.

Coelho, P. and R. McGuire 1999. Biology, disease and economics: An epidemiological history of slavery in the American South. Journal of Bioeconomics 1: 151-190. https: //doi.org/10.1023/A:1010034830415

Cole, T. 2003. The secular trend in human physical growth: A biological view. Economics and Human Biology 1(2): 161-168. https://doi.org/10.1016/S1570-677X(02)00033-3

Costa, D. 1993, Height, weight, wartime stress, and older-age mortality: Evidence from the union army records. Explorations in Economic History 30(4): 424-449. https://doi.org/10. 1006/exeh.1993.1018

Costa, D. 2015. Health and the economy in the United States from 1750 to the present. Journal of Economic Literature 53(3): 503-579. https://doi.org/10.1257/jel.53.3.503

Costa, D. and R. Steckel 1997. Long-term trends in health, welfare and economic growth in the United States. In Health and welfare during industrialisation, eds R. Steckel and R. Floud, 47-89. Chicago: University of Chicago Press.

Crafts, N. 1992. Review of R. Floud, K. Wachter and A. Gregory, Height, health and history: Nutritional status in the United Kingdom. Economic History Review 45(2): 427-428. https://doi.org/10.1111/j.1468-0289.1992.tb01309.x 
Crafts, N. 1997. Dimensions of the "quality of life" during the British industrial revolution. Economic History Review 50(4): 617-639. https://doi.org/10.1111/1468-0289.00071

Dasgupta, P. and D. Ray 1990. Adapting to undernourishment: The biological evidence and its implications. In The political economy of hunger. Vol. 1: Entitlement and wellbeing, eds J. Drèze and A. Sen, 191-246. Oxford: Clarendon Press.

Deaton, A. and R. Arora 2009. Life at the top: the benefits of height. Economics and Human Biology 7(2): 133-136. https://doi.org/10.1016/j.ehb.2009.06.001

Depauw, E. and D. Oxley 2019. Toddlers, teenagers and terminal heights: The importance of puberty for male adult stature, Flanders 1800-76. Economic History Review 72(3): 925-952. https://doi.org/10.1111/ehr.12745

Eltis, D. 1982. Nutritional trends in Africa and the Americas: Heights of Africans, 1819-1839. Journal of Interdisciplinary History 12(3): 453-475. https://doi.org/10.2307/203269

Eveleth, P. and J. Tanner 1976. Worldwide variation in human growth. First edition. Cambridge: Cambridge University Press.

Eveleth, P. and J. Tanner 1990. Worldwide variation in human growth. Second edition. Cambridge: Cambridge University Press. https://doi.org/10.1017/CBO9780511629105

Ezzati, M. et al. 2016. A century of trends in adult human height. eLife, 5: e13410. https: //doi.org/10.7554/eLife.13410

Feinstein, C. H. 1998. Pessimism perpetuated: Real wages and the standard of living in Britain during and after the industrial revolution. Journal of Economic History 58(3): 625-658. https://doi.org/10.1017/S0022050700021100

Floud, R. 1984a. Measuring the transformation of the European economies: Income, health and welfare. CEPR Discussion Papers 33. London: Centre for Economic Policy Research.

Floud, R. 1984b. The heights of Europeans since 1750: A new source for European economic history'. NBER Working Papers No. 1318. https://doi.org/10.3386/w1318

Floud, R. 1994. The heights of Europeans since 1750: A new source for European economic history. Stature, living standards and economic development, ed J. Komlos, 9-24. Chicago: University of Chicago Press.

Floud, R. 1997. The people and the British economy 1830-1914. Oxford: Oxford University Press.

Floud, R. and B. Harris 1997. Health, height and welfare: Britain 1700-1980. In Health and welfare since industrialisation, eds R. Steckel and R. Floud, 91-126. Chicago: Chicago University Press.

Floud, R., R. Fogel, B. Harris and S. C. Hong 2011. The changing body: Health, nutrition and human development in the western world since 1700. Cambridge: Cambridge University Press.

Floud, R., B. Harris and S. C. Hong 2014. Introduction. In Health, mortality and the standard of living in Europe and North America since 1700, eds R. Floud, R. Fogel, B. Harris and S. C. Hong, vol. 1, xiii-xlii. Cheltenham: Edward Elgar.

Floud, R., K. Wachter and A. Gregor 1990. Height, health and history: Nutritional status in the United Kingdom 1750-980, Cambridge: Cambridge University Press.

Floud, R., K. Wachter and A. Gregory 1993a. Measuring historical heights: Short cuts or the long way round? A reply to Komlos. Economic History Review 46(1): 145-154. https://doi.org/10.1111/j.1468-0289.1993.tb01326.x 
Floud, R., K. Wachter and A. Gregory 1993b. Further thoughts on the nutritional status of the British population. Economic History Review 46(2): 367-368. https://www.jstor.org/ stable/2598023

Fogel, R. 1986. Nutrition and the decline in mortality since 1700: Some preliminary findings. In Long-term factors in American economic growth, eds S. Engerman and R. Gallman, 439555. Chicago: University of Chicago Press. https://doi.org/10.7208/9780226209319-010

Fogel, R., S. Engerman, J. Trussell, R. Floud, C. Pope and L. Wimmer 1978. The economics of mortality in North America, 1650-1910: A description of a research project. Historical Methods 11(2): 75-108. https://doi.org/10.1080/01615440.1978.9955221

Friedman, G. 1982. The heights of slaves in Trinidad. Social Science History 6(4): 482-515. https://doi.org/10.2307/1170973

Gallardo-Albarrán, D. and H. DeJong 2021. Optimism or pessimism? A composite view on English living standards during the industrial revolution. European Review of Economic History 25(1): 1-19. https://doi.org/10.1093/ereh/heaa002

Galofré-Vilà, G. 2018. Growth and maturity: A quantitative systematic review and network analysis in anthropometric history. Economics and Human Biology 28: 107-118. https://doi.org/10.1016/j.ehb.2017.12.003

Galofré-Vilà, G., A. Hinde and A. Guntupalli 2018. Heights across the last 2000 years in England. Research in Economic History 34: 67-98. https://doi.org/10.1108/S0363326820180000034003

Gao, P. and E. Schneider 2020. The growth pattern of British children, 1850-1975. Economic History Review. https://doi.org/10.1111/ehr.13002

Grasgruber, P., J. Cacek, T. Kalina and M. Sebera 2014. The role of nutrition and genetics as key determinants of the positive height trend. Economics and Human Biology 15(1): 81-100. https://doi.org/10.1016/j.ehb.2014.07.002

Grasgruber, P., M. Sebera, Hrazdíra, E., J. Cacek and T. Kalina 2016. Major correlates of male height: a study of 105 countries. Economics and Human Biology 21: 172-195. https://doi.org/10.1016/j.ehb.2016.01.005

Gruenwald, P., H. Funakawa, S. Mitani, T. Nishimura and S. Takeuchi 1967. Influence of environmental factors on foetal growth in man. Lancet 289(7498): 1026-1029. https://doi.org/10.1016/S0140-6736(67)91541-3

Harris, B. 1993. The demographic impact of the First World War: An anthropometric perspective. Social History of Medicine 6(3): 343-66. https://doi.org/10.1093/shm/6.3.343

Harris, B. 1997. Growing taller, living longer? Anthropometric history and the future of old age. Ageing and Society 17(5): 491-512. https://doi.org/10.1017/S0144686X97006594

Harris, B. 2001. Height and nutrition. In The Cambridge world history of food, eds K. Kiple and K. C. Ornelas, vol. 2, 1427-1438. New York: Cambridge University Press. https://doi.org/10.1017/CHOL9780521402156.032

Harris, B. 2008a. Review of S. Kunitz, The health of populations: General theories and particular realities. Economics and Human Biology 6(3): 492-494. https://doi.org/10. 1016/j.ehb.2008.07.005

Harris, B. 2008b. Gender, health and welfare in England and Wales since industrialisation. Research in Economic History 26: 157-204. https://doi.org/10.1016/S0363-3268(08) 26003-9 
Harris, B. 2009. Anthropometric history, gender and the measurement of wellbeing. In Gender and wellbeing in Europe: Historical and contemporary perspectives, eds B. Harris, L. Gálvez and H. Machado, 59-84. Farnham: Ashgate.

Harris, B. 2014. Health and welfare. In The Cambridge economic history of modern Britain, eds R. Floud, J. Humphries and P. Johnson, Vol. 2. 1870-2010, 122-150. Cambridge: Cambridge University Press.

Harris, B. 2016. Food supply, health and economic development in England and Wales during the eighteenth and nineteenth centuries. Scientia Danica, Series H, Humanistica 4(7): 139-152. http://publ.royalacademy.dk/backend/web/uploads/2020-02-14/AFL\% 206/SDH4_7_00_00_2016_5868/SDH4_7_00_00_2016_5868.pdf.

Harris, B. and J. Helgertz 2019. Urban sanitation and the decline of mortality. History of the Family 24(2): 207-26. https://doi.org/10.1080/1081602X.2019.1605923

Harris, B., R. Floud and S. C. Hong 2015. How many calories? Food availability in England and Wales in the 18th and 19th centuries. Research in Economic History 31: 111-191. https://doi.org/10.1108/S0363-326820150000031003

Hatton, T. 2011. Infant mortality and the health of survivors: Britain, 1910-50. Economic History Review 64(3): 951-972. https://doi.org/10.1111/j.1468-0289.2010.00572.x

Hatton, T. 2014. How have Europeans grown so tall?. Oxford Economic Papers 66(2): 349-372. https://doi.org/10.1093/oep/gpt030

Hatton, T. and B. Bray 2010. Long run trends in the heights of European men, 19th-20th centuries. Economics and Human Biology 8(3): 405-413. https://doi.org/10.1016/j.ehb. 2010.03.001

Hatton, T. and R. Martin 2010. The effects on stature of poverty, family size and birth order: British children in the 1930s. Oxford Economic Papers 62(1): 157-184. https: //doi.org/10.1093/oep/gpp034

Hermanussen, M., R. Largo and L. Molina 2001. Canalisation in human growth: A widely accepted concept reconsidered. European Journal of Pediatrics 160(3): 163-167. https://doi.org/10.1007/s004310000706

Hong, S. C. 2007. The burden of early exposure to malaria in the United States, 1850-1860: malnutrition and immune disorders. Journal of Economic History 67(4): 1001-1035. https://doi.org/10.1017/S0022050707000472

Horrell, S., D. Meredith and D. Oxley 2009. Measuring misery: Body mass, ageing and gender inequality in Victorian London. Explorations in Economic History 46(1): 93-119. https://doi.org/10.1016/j.eeh.2007.12.001

Howe, P. and M. Schiller 1952. Growth responses of the school child to changes in diet and environmental factors. Journal of Applied Physiology 5(2): 51-61. https://doi.org/10. 1152/jappl.1952.5.2.51

Jones, C. and P. Klenow 2016. Beyond GDP: Welfare across countries and time. American Economic Review 106(9): 2426-2457. https://doi.org/10.1257/aer.20110236

Koepke, N. and J. Baten 2005. The biological standard of living in Europe during the last two millennia. European Review of Economic History 9(1): 61-95. https://doi.org/10.1017/ S1361491604001388

Koepke, N. and J. Baten 2008. Agricultural specialisation and height in ancient and medieval Europe. Explorations in Economic History 45(2): 127-146. https://doi.org/10.1016/j.eeh. 2007.09.003 
Koepke, N., J. Floris, C. Pfister, F. Rühli and K. Staub 2018. Ladies first: Female and male adult height in Switzerland, 1770-1930. Economics and Human Biology 29: 76-87. https://doi.org/10.1016/j.ehb.2018.02.002

Komlos, J. 1987. The height and weight of West Point cadets: Dietary change in anetebellum America. Journal of Economic History 47(4): 897-927. https://doi.org/ 10.1017/S002205070004986X

Komlos, J. 1993a. The secular trend in the biological standard of living in the United Kingdom, 1730-1860. Economic History Review 46(1): 115-144. https://www.jstor.org/ stable/2597683

Komlos, J. 1993b. Further thoughts on the nutritional status of the British population. Economic History Review 46(2): 363-366. https://doi.org/10.1111/j.1468-0289.1993. tb01338.x

Komlos, J. 2004. How to and how not to analyse deficient height samples. Historical Methods 17(4): 160-173. https://doi.org/10.3200/HMTS.37.4.160-173

Komlos, J. 2019. Shrinking in a growing economy is not so puzzling after all. Economics and Human Biology 32: 40-55. https://doi.org/10.1016/j.ehb.2018.11.005

Komlos, J. and B. A'Hearn 2016. The decline in the nutritional status of the U.S. antebellum population at the onset of modern economic growth. NBER Working Papers No. 21845. https://doi.org/10.3386/w21845

Komlos, J. and B. A'Hearn 2019. Clarifications of a puzzle: The decline in nutritional status at the onset of modern economic growth in the USA. Journal of Economic History 79(4): 1129-53. https://doi.org/10.1017/S0022050719000573

Komlos, J. and H. Küchenhoff 2012. The diminution of the physical stature of the English male population in the eighteenth century. Cliometrica 6(1): 45-62. https://doi.org/10. 1007/s11698-011-0070-7

Kopczyński, M. and M. Rodak 2020. The Polish interbella puzzle: The biological standard of living in the Second Polish Republic. Economic History Review 74(1):181-203. https://doi.org/10.1111/ehr.13046

Leon, D., I. Koupilova, H. Lithell, L. Berglund, R. Mohsen, D. Vågerö, U.-B. Lithell and P. McKeigue 1996. Failure to realise growth potential in utero and adult obesity in relation to blood pressure in 50-year old Swedish men. British Medical Journal 312(7028): 401-406. https://doi.org/10.1136/bmj.312.7028.401

Ling, J. and N. King 1987. Secular trends in stature and weight in southern Chinese children in Hong Kong. Annals of Human Biology 14(2): 187-190. https://doi.org/10. 1080/03014468700006912

Margo, R. and R. Steckel 1982. The heights of American slaves: New evidence on slave nutrition and health. Social Science History 6(4): 516-538. https://doi.org/10.2307/ 1170974

McKeown, T. 1976. The modern rise of population. London: Edward Arnold.

McKeown, T. and R. Brown 1955. Medical evidence related to English population changes in the eighteenth century. Population Studies 9(2): 119-141. https://doi.org/10.1080/ 00324728.1955.10404688

McKeown, T. and R. Record 1962. Reasons for the decline of mortality in England and Wales during the nineteenth century. Population Studies 16(2): 94-122. https://doi.org/10. $1080 / 00324728.1962 .10414870$ 
McKeown, T., R. Brown and R. Record 1972. An interpretation of the modern rise of population in Europe. Population Studies 26(3): 345-382. https://doi.org/10.1080/ 00324728.1972.10405908

Meinzer, N., R. Steckel and J. Baten 2019. Agricultural specialisation, urbanisation, workload and stature. In The backbone of Europe: Health, diet, work and violence over two millennia, eds R. Steckel, C. S. Larsen, C. Roberts and J. Baten, 231-252. Cambridge: Cambridge University Press. https://doi.org/10.1017/9781108379830.010

Meredith, D. and D. Oxley 2014. Food and fodder: Feeding England, 1700-1900. Past and Present 222: 163-214. https://doi.org/10.1093/pastj/gtt020

Mokyr, J. and Ó Gráda, C. 1996. Height and health in the United Kingdom, 1815-60: evidence from the East India Company Army. Explorations in Economic History 33(2): 141-168. https://doi.org/10.1006/exeh.1996.0007

Murray, J. 2000. Marital protection and marital selection: Evidence from a historicalprospective sample of American men. Demography 37(4): 511-521. https://doi.org/10. 1353/dem.2000.0010

NCD Risk Factor Collaboration (NCD-RisC) 2020. Height and body-mass index trajectories of school-aged children and adolescents from 1985 to 2019 in 200 countries and territories: A pooled analysis of 2181 population-based studies with 65 million participants. Lancet 396: 1511-1524. https://doi.org/10.1016/S0140-6736(20)31859-6

Öberg, S. 2017. Too many is not enough: Studying how children are affected by their number of siblings and resource dilution in families. History of the Family 22(2-3): 157-174. https://doi.org/10.1080/1081602X.2017.1302890

Oddy, D. 1982. The health of the people. In Population and society in Britain, 1850-1980, eds T. Barker and M. Drake, 121-140. London: Batsford.

Osmani, S. and Sen A. 2003. The hidden penalties of gender inequality: Fetal origins of ill-health. Economics and Human Biology 1(1):105-121. https://doi.org/10.1016/S1570677X(02)00006-0

Perkins, J., S. Subramanian, G. Davey Smith and E. Özaltin 2016. Adult height, nutrition and population health. Nutrition Reviews 74(3): 149-165. https://doi.org/10.1093/nutrit/ nuv105

Prados de la Escosura, L. 2019. Human development in the age of globalisation. European Historical Economics Society Working Paper Series 157. http://www.ehes. org/EHES_157.pdf

Prentice, A. M., K. Ward, G. Goldberg, M. J. Landing, S. Moore, A. Fulford and A. Prentice 2013. Critical windows for nutritional interventions against stunting. American Journal of Clinical Nutrition 97(5): 911-918. https://doi.org/10.3945/ajen.112.052332

Schneider, E. and K. Ogasawara 2018. Disease and child growth in industrialising Japan: Critical windows and the growth pattern, 1917-39. Explorations in Economic History 69: 64-80. https://doi.org/10.1016/j.eeh.2018.05.001

Schultz, T. P. 2002. Wage gains associated with height as a form of health human capital. American Economic Review 92(2): 349-353. https://doi.org/10.1257/ 000282802320191598

Sen, A. 1987. The standard of living. Cambridge: Cambridge University Press.

Sen, A. 1999. Development as freedom. Oxford: Oxford University Press. 
Sharpe, P. 2012. Explaining the short stature of the poor: Chronic childhood disease and growth in nineteenth-century England. Economic History Review 65(4): 1475-1494. https://doi.org/10.1111/j.1468-0289.2011.00629.x

Silventoinen, K. 2003. Determinants of variation in adult body height. Journal of Biosocial Science 35(2): 263-285. https://doi.org/10.1017/S0021932003002633

Sinclair, D. 1978. Human growth after birth. Third edition. London: Oxford University Press.

Singhal, A. 2017. Long-term adverse effects of early growth acceleration of catch-up growth. Annals of Nutrition and Metabolism 70: 236-240. https://doi.org/10.1159/000464302

Sohn, K. 2015. The value of male height in the marriage market. Economics and Human Biology 18: 110-124. https://doi.org/10.1016/j.ehb.2015.05.004

Steckel, R. 1983. Height and per capita income. Historical Methods 16(1): 1-7. https://doi.org/10.1080/01615440.1983.10594092

Steckel, R. 1986. A peculiar population: The nutrition, health and mortality of American slaves from childhood to maturity. Journal of Economic History 46(3): 721-741. https://doi.org/10.1017/S0022050700046842

Steckel, R. 1992. Stature and living standards in the United States. In American economic growth before the civil war, eds R. Gallman and J. Wallis, 265-308. Chicago: University of Chicago Press. https://doi.org/10.7208/9780226279473-008

Steckel, R. 1995. Stature and the standard of living. Journal of Economic Literature 33(4): 1903-1940. https://www.jstor.org/stable/2729317

Steckel, R. 2008. Biological measures of the standard of living. Journal of Economic Perspectives 22(1): 129-152. https://doi.org/10.1257/jep.22.1.129

Steckel, R. 2009. Height and human welfare: Recent developments and new directions. Explorations in Economic History 46(1): 1-23. https://doi.org/10.1016/j.eeh.2008.12.001

Steckel, R. 2016. Biological measures of wellbeing. In The Oxford handbook of economics and human biology, eds J. Komlos and I. Kelly, 32-51. New York: Oxford University Press. https://doi.org/10.1093/oxfordhb/9780199389292.013.25

Steckel, R., C. S. Larsen, C. Roberts and J. Baten (eds) 2019. The backbone of Europe: Health, diet, work and violence over two millennia. Cambridge: Cambridge University Press.

Szreter, S. and G. Mooney 1998. Urbanisation, mortality and the standard of living debate: New estimates of the expectation of life at birth in nineteenth-century British cities. Economic History Review. 51(1): 84-112. https://doi.org/10.1111/1468-0289.00084

Tanner, J. 1962. Growth at adolescence, with a general consideration of the effects of hereditary and environmental factors upon growth and maturation from birth to maturity. Second edition. Oxford: Blackwell.

Tanner, J. 1987. Growth as a mirror of the condition of society: Secular trends and class distinctions. Pediatrics International 29(1): 96-103. https://doi.org/10.1111/j.1442-200X. 1987.tb00015.x

Tanner, J. 1990. Fetus into man: Physical growth from conception to maturity. Second edition. Cambridge, MA: Harvard University Press.

Tanner, J., T. Hayashi, M. Preece and N. Cameron 1982. Increase in length of leg relative to trunk size in Japanese children from 1957 to 1977: Comparisons with British and with Japanese Americans. Annals of Human Biology 9(5): 411-423. https://doi.org/10.1080/ 03014468200005951 
Tanner, J., R. Whitehouse and M. Takaishi 1966. Standards from birth to maturity for height, weight, height velocity, weight velocity: British children, 1965: Part II. Archives of Disease in Childhood 41(220): 613-635. http://doi.org/10.1136/adc.41.220.613

Usher, D. 1980. The measurement of economic growth. Oxford: Blackwell.

Villermé, L. R. 1829. Mémoire sur la taille de l'homme en France. Annales d'Hygiène Publique 1: 351-399.

Visscher, P. 2008. Sizing up human height variation. Nature Genetics 40(5): 489-490. https://doi.org/10.1038/ng0508-489

Waaler, H. 1984. Height, weight and mortality: The Norwegian experience. Acta Medica Scandinavica 215(S679): 1-56. https://doi.org/10.1111/j.0954-6820.1984.tb12901.x

Waddington, C. H. 1942. Canalization of development and the inheritance of acquired characteristics. Nature 150: 563-565. https://doi.org/10.1038/150563a0

Weitzman, A. and D. Conley 2014. From assortative to ashortative coupling: Men's height, height heterogamy, and relationship dynamics in the United States. NBER Working Papers No. 20402. https://doi.org/10.3386/w20402

Wells, J. C. K. 2016. The metabolic ghetto: An evolutionary perspective on nutrition, power relations and chronic diseases. Cambridge: Cambridge University Press. https://doi.org/ 10.1017/CBO9780511972959

Yamamura, E. and Y. Tsutsui 2017. Comparing the role of the height of men and women in the marriage market. Economics and Human Biology 26: 42-50. https://doi.org/10.1016/j. ehb.2017.02.006

Zimran, A. 2019. Sample-selection bias and height trends in the nineteenth-century United States. Journal of Economic History 79(1): 99-138. https://doi.org/10.1017/ S0022050718000694

Open Access This article is published under the terms of the Creative Commons Attribution 4.0 International License (https://creativecommons.org/licenses/by/4.0/) that allows the sharing, use and adaptation in any medium, provided that the user gives appropriate credit, provides a link to the license, and indicates if changes were made. 